\title{
EFFECT OF FEEDING GUAVA WASTE ON GROWTH PERFORMANCE, DIET DIGESTIBILITY, CARCASS CHARACTERISTICS AND PRODUCTION PROFITABILITY OF OSSIMI LAMBS
}

\author{
Tamer M.M. Hassan ${ }^{1, *}$; Fathy A.I. Abdel-Fattah ${ }^{2}$; Ayman S. Farid ${ }^{3}$; and Eman R. Kamel ${ }^{4}$ \\ ${ }^{1}$ Department of Animal Production, Faculty of Agriculture, Benha University, Egypt. \\ ${ }^{2}$ Department of Nutrition and Clinical Nutrition, Faculty of Veterinary Medicine, Benha University, Egypt. \\ ${ }^{3}$ Department of Clinical Pathology, Faculty of Veterinary Medicine, Benha University, Egypt. \\ ${ }^{4}$ Department of Animal Wealth Development, Faculty of Veterinary Medicine, Benha University, Egypt. \\ "Corresponding author: tamer.mohamed@ fagr.bu.edu.eg.
}

(Received 7/2/2016, Accepted 15/5/2016)

SUMMARY

$\mathrm{T}$

The present study was designed to investigate the effect of including dried guava waste $(\mathrm{GW})$ in diets of Ossimi lambs on growth performance, apparent diet digestibility, carcass characteristics and economic efficiency. Eighteen Ossimi male lambs (average body weight of $28.4 \pm 1.7 \mathrm{~kg}$ ) were divided randomly into three experimental groups (6 lambs each). Control group was fed diet based on corn and soybean meal, GW was added as a feed ingredient in the diet at levels of $10 \%$ and $20 \%$ and fed to other groups (D1 and D2), respectively for 12 weeks. Animals were housed individually in clean and hygienic pens. Body weight was measured weekly and feed consumption was recorded daily. Digestibility trial was conducted and digestion coefficient was calculated for diet dry matter (DM) and nutrients. At the end of study, three animals from each group were slaughtered and carcass traits were evaluated. At the end of experiment, blood samples were collected for analysis and serum biochemistry. Economic feasibility was evaluated for using GW in the diet. Results showed that there were no significant differences between groups in growth performance parameters between groups. Similar findings were recorded for digestibility of DM and nutrients. Addition of $10 \%$ and $20 \%$ of GW in the diets did not negatively affect blood picture or serum biochemistry and results showed no significant differences in carcass traits and meat analysis. Economical profitability was significantly found when feeding $20 \% \mathrm{GW}$ in the diet. It can be concluded that GW can be utilized effectively at a level of $20 \%$ of the diet without adverse effect on performance, digestibility, carcass traits or health parameters of Ossimi lambs.

Keywords: Guava waste, sheep, growth performance, economic efficiency, digestion coefficient and carcass.

\section{INTRODUCTION}

In Egypt and many other countries, millions of tons from agro-industrial wastes are produced. When these wastes are accumulated without treatment, they adversely affect the environment. Recently, the growth of animal feed industry has allowed considerable use of agro-industrial by-products that can be properly included in animal feeds. Various agro-industrial wastes and other non-conventional feedstuffs have been evaluated as potential feed ingredients for farm animals (Asmare et al., 2010 and Shi et al., 2014). The concern for using these alternative feed has increased, especially for reducing the nutritional deficit between animal requirements and feed resource, as the feed costs constitute more than $70 \%$ of the total production costs in any livestock enterprise (Al-shanti et al., 2013 and Lira et al., 2009). The use of plant by-products for animal nutrition is an area of increasing research importance. For the agro-food industry, the use of its coproducts in animal feeding represents a mean of nutrient recycling and should be taken into account as a preference way of by-product elimination. Accordingly, the use of agro-industrial wastes can be expected to have a favorable economic effect and a reduction of the environmental encumbrance. Egyptian guava

Issued by The Egyptian Society of Nutrition and Feeds 


\section{Hassan et al.}

(Psidium guaijava L.) is an important tropical and semitropical, fruits yellow in color and is processed for human nutrition as beverages, puree, jam, canned slices, syrup concentrate and juices.

Guava waste $(\mathrm{GW})$ as one of the agro-industrial by-products contains nutrients in addition to bioactive antioxidant compounds that are capable of preventing the oxidative damage caused by free radicals (Melo et al., 2011 and Omena et al., 2012). The seeds, pulp and peels are the main components of the waste product processing industries and they are not yet used for any beneficial purpose. The chemical composition of GW in some literatures revealed that its content of crude protein $(\mathrm{CP})$ was ranged from 8.60 to $10.09 \%$, ether extract (EE) was in the range of 9.69 to $11.68 \%$ (Lira et al., 2011; El Deek et al., 2009a and Santos et al.,2009), crude fiber (CF) was between 56.01 and 60.08\% (Lira et al.,2011). It was found that GW contains high proportion of dietary antioxidant fiber in addition to polyphenolic compounds (El Deek et al., 2009a) that provide health benefits for human and animals (Uddin et al., 2002). In this trend, GW can be used as feed ingredient for ruminants that able to utilize inexpensive by-products to meet their requirements for maintenance, growth and production (Macias-Cruz et al., 2010).

The aim of this study was to evaluate the effect of utilizing dried GW as a feed ingredient in the diet of growing sheep on growth performance, digestibility, carcass characteristics, blood parameters and economic efficiency.

\section{MATERIALS AND METHODS}

\section{Experimental design and dietary treatments}

Eighteen Ossimi male lambs (mean weight of $28.4 \pm 1.7 \mathrm{~kg}$ ) were obtained from the experimental farm of the Faculty of Agriculture, Moshtohor, Benha University. The animals were randomly divided into three equal experimental groups $(n=6)$. Lambs were housed individually in clean and hygienic pens $(0.97 \mathrm{~m} \times$ $2.82 \mathrm{~m}$ ). Lambs were subjected to the routine vaccination program against infectious diseases and also deworming program just before the start of the experiment. At the same time, the experimental animals were sprayed by the suitable pesticides when needed. GW were collected from Vitrac ${ }^{\circledR}$ Company for food processing, Qalyubia, Egypt then dried and crushed in disc crusher, well mixed and stored in a well-ventilated place until utilizing in the diet formulation.

Three experimental diets (Table 1) were formulated according to the nutrient requirements of sheep (NRC, 1985). One basal control and two diets containing 10\% (D1) and 20\% (D2) of GW were formulated and prepared. After an adaptation period of 7 days, diets were weighed and offered to the animals twice daily at 8:00 am and at 4:00 pm with allowance of 15\% refusal in equal quantities for each group. Both of the consumed diets and refusals, if any, were recorded daily. Clean and fresh water with salt lick were also offered ad libitum. All lambs were weighed individually every week to the nearest $\mathrm{kg}$ in the morning before feeding throughout the experimental period (84 days). Total body weight gain (TBWG), Average daily weight gain (ADWG), total and daily feed intake (TFI, DFI) and feed conversion ratio (FCR) were then calculated.

\section{Digestibility trial}

After three weeks preliminary period, a digestibility trial was carried out for determination of the digestion coefficient (DC) of diet dry matter (DM) and nutrients. A stainless steel wire mesh was placed on the floor to keep fecal matter away from urine, which was passed through a stream into drainage. Feed intake was daily recorded. Feces were collected, mixed and weighed at morning for successive 7 days then stored at $-20^{\circ} \mathrm{C}$ till analysis. Fecal samples $(10 \%)$ were taken daily and dried out at $60^{\circ} \mathrm{C}$ for $48 \mathrm{~h}$ and ground. Feed and fecal samples were analyzed according to AOAC (1995). Dry matter was measured using hot air circulation oven (Heraeus Ut20, Germany) at $105{ }^{\circ} \mathrm{C}$ for 3 hours. Crude protein was measured using Kjeltec ${ }^{\circledR}$ system 2100, FOSS-Sweden. Ether extract (EE) was determined by Soxtec ${ }^{\circledR}$ system 2045, FOSS-Sweden. Crude fiber (CF) was measured using the method of Van Soestet al. (1991) by Fibretherm ${ }^{\circledR}$ system, GerhardtGermany. The DC of diet was calculated for DM, CP, EE, CF and nitrogen-free extract (NFE) from each dietary treatment using the equation proposed by McDonald et al. (2002).

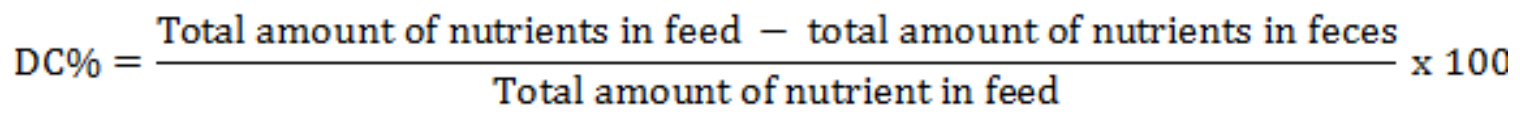


Table (1). Feed formulation and analysis of complete diets fed to experimental groups.

\begin{tabular}{|c|c|c|c|}
\hline Feed ingredient & Control & D1 & D2 \\
\hline $\mathrm{GW}^{*}$ & 00.00 & 10.00 & 20.00 \\
\hline Yellow corn & 31.10 & 31.80 & 32.70 \\
\hline Soybean meal (44\%CP) & 18.00 & 15.20 & 14.00 \\
\hline Wheat bran & 05.00 & 10.80 & 15.50 \\
\hline Wheat straw & 23.20 & 09.50 & 00.00 \\
\hline Cottonseed meal & 04.00 & 04.00 & 04.00 \\
\hline Molasse & 05.00 & 05.00 & 05.00 \\
\hline Egyptian clover & 10.00 & 10.00 & 05.00 \\
\hline Sodium bicarbonate & 00.50 & 00.50 & 00.50 \\
\hline Vitamins and minerals mixture ${ }^{* *}$ & 00.30 & 00.30 & 00.30 \\
\hline Salt & 00.70 & 00.70 & 00.70 \\
\hline Limestone & 01.20 & 01.40 & 01.80 \\
\hline Dicalcium phosphate & 00.50 & 00.30 & 00.00 \\
\hline Ammonium chloride & 00.50 & 00.50 & 00.50 \\
\hline Total & 100.0 & 100.0 & 100.0 \\
\hline \multicolumn{4}{|c|}{ Calculated analysis (\% on dry matter basis) ${ }^{* * * *}$} \\
\hline Metabolizable energy (ME, Mcal/kg) & 02.50 & 02.58 & 02.66 \\
\hline $\mathrm{CP}$ & 15.16 & 15.20 & 15.15 \\
\hline $\mathrm{CF}$ & 15.96 & 16.60 & 17.60 \\
\hline NDF & 32.35 & 30.38 & 29.16 \\
\hline ADF & 20.67 & 20.00 & 19.80 \\
\hline Calcium & 00.87 & 00.88 & 00.88 \\
\hline Total phosphorus & 00.44 & 00.49 & 00.50 \\
\hline \multicolumn{4}{|c|}{$\begin{array}{l}\text { GW composition (DM }=94.35 \% ; C P=7.53 \% ; E E=18.93 \% ; C F=59.21 \% ; A s h=1.27 \% ; N F E=7.41 \%) \text { according to } \\
\text { Kamel et al. }(2016) \text {. }\end{array}$} \\
\hline \multicolumn{4}{|c|}{ ME was estimated according to El-Deek et al. (2009b) } \\
\hline \multicolumn{4}{|c|}{$\begin{array}{l}\text { Purchased by Misr Feed Additives for animal nutrition, Egypt. Each } 3 \text { kgcontain: Vitamin } \mathrm{A}=12,000,000 \mathrm{IU}, D_{3}=30,000 \mathrm{mg}, \text { Iodine } \\
2,500,000 \mathrm{IU}, \text { E }=15,000 \mathrm{mg} \text {, Zinc }=60,000 \mathrm{mg} \text {, Manganese }=70,000 \mathrm{mg}, \text { Iron }=60,000 \mathrm{mg}, \text { Copper }=30,000 \text {, and Calcium carbonate up to } 3 \mathrm{~kg} .\end{array}$} \\
\hline ****alculated according to feed compositic & sheep $(19$ & & \\
\hline
\end{tabular}

\section{Blood picture and chemistry}

At the end of experiment, two blood samples were collected from the jugular vein of all animals. One sample was taken on EDTA for hematological parameters, including white blood cells (WBCs), red blood cells (RBCs), hemoglobin ( $\mathrm{Hb})$ concentration, packed cell volume (PCV), mean corpuscular volume (MCV), mean corpuscular hemoglobin $(\mathrm{MCH})$, mean corpuscular hemoglobin concentration (MCHC) and percentages of lymphocytes, monocytes and granulocytes using an electronic particle hematology analyzer (HA22/20/ Vet Clindiag; Clindiag Systems B.V.B.A., Steenberg 66, Pollare/Ninove (9401), Belgium). The second blood sample was collected in plain tubes and centrifuged at $3000 \mathrm{rpm}$ (Sigma 3-18K) for measurement of serum total protein, albumin and globulin according to Belifield and Goldberg (1971), urea and creatinine according to Husdan and Rapaport (1968). Also blood glucose and total cholesterol were measured.

\section{Carcass characteristics}

At the end of experimental period ( 84 days), three lambs from each group were weighed after $18 \mathrm{hrs}$ fasting and then slaughtered for carcass evaluation (Bellaver et al., 1983). After complete bleeding by hanging the animals in a head down position, carcass was skinned and dressed out. The internal organs were removed from the abdomen and the hot carcass weight was recorded. Dressing percentage was calculated using the following formula:

$$
\text { Dressing percentage }=\frac{\text { Hot carcass weight }}{\text { Empty body weight }} \times 100
$$




\section{Hassan et al.}

Where, Empty body weight = body weight after complete bleeding and removing of digestive tract.

Weights of heart, spleen, kidneys, liver and testes were recorded to the nearest kilogram.

For each slaughtered lamb, weights of all available prime cuts (round, loin, rack and shoulder) and second cuts (neck, brisket, flank and tail) were measured. Meat section of the rib-eye area (lean and fat) of 9, 10 and $11^{\text {th }}$ rib from each carcass was cut vertically to the vertebral column according to Hankins and Howe (1946). The meat samples of rib-eye area were ground, homogenized and frozen until subsequent analysis. Analysis of moisture, fat, protein and ash in meat was carried out according to AOAC (1995) after thawing for overnight in refrigerator at $4^{\circ} \mathrm{C}$.

\section{Economic efficiency measures}

The most important economic efficiency parameters investigated in this study are cost parameters, return parameters and net profits. The cost parameters included the total variable cost (TVC), total fixed cost (TFC) and total cost (TC) according to El-Tahaway (2007), Liza (2012) and Omar (2009). The TVC includes the price of the purchased sheep, feed price and GW costs. It was estimated in Egyptian Pound (LE) over the course of experiment. For TFC, the costs of labor, veterinary care (drugs, vaccines and veterinary supervision), water, electricity, in addition to costs of litter and building depreciation were calculated per animal for each group. Hence, all these parameters were considered fixed costs for each animal used in the experiment. The building was depreciated over 25 years and the equipment over 5 years. The TC was computed as the sum of TFC and TVC (Sankhyan, 1983). Total returns (TR) included the values of final body weight, wool and litter sale. Net profit (NP) was calculated by finding the difference between the TR and TC.

\section{Statistical analysis}

Shapiro Wilks test was used to examine whether variables were distributed normally. Following data distribution, differences between study groups were analyzed by analysis of variance (ANOVA) and Duncan's multiple comparison Post Hoc tests (Duncan, 1955). Statistical analysis was performed using the statistical software package SPSS for Windows (version 20.0; SPSS Inc., Chicago, IL, USA). Statistical significance between mean values was set at $P<0.05$ and data were reported as means and standard error of mean (SEM).

\section{RESULTS AND DISCUSSION}

In the present study, dried GW was used as a low-cost feed ingredient in lamb feeding (10\% and $20 \%$ of the diet). The main lamb performance parameters, with values of final live-weight, TFI, DFI, TBWG, ADWG, and FCR are summarized in Table (2).

Table (2). Growth performance of growing lambs fed the experimental diets.

\begin{tabular}{lccccc}
\hline Item & Unit & Control & D1 & D2 & SEM $^{*}$ \\
\hline Initial weight & $\mathrm{kg}$ & 28.41 & 28.58 & 28.33 & 1.7 \\
Final weight & $\mathrm{kg}$ & 48.16 & 48.50 & 49.83 & 2.00 \\
Total feed intake (TFI) & $\mathrm{kg}$ & 124.13 & 125.71 & 125.42 & 2.14 \\
Daily feed intake (DFI) & $\mathrm{kg}$ & 1.48 & 1.50 & 1.49 & 0.051 \\
Total body weight gain (TBWG) & $\mathrm{kg}$ & 19.75 & 19.58 & 20.50 & 0.76 \\
Average daily weight gain (ADWG) & $\mathrm{g}$ & 235 & 233 & 244 & 9 \\
Feed conversion ratio (FCR) & & 6.49 & 6.60 & 6.12 & 0.23 \\
\hline
\end{tabular}

SEM - Standard error of mean

It was indicated that body weight is generally used to express growth performance of animals (Adeyinka and Mohammed, 2006). Results of the final live body weight, weight gain and FCR showed insignificant improvement $(P>0.05)$ for lambs fed diet contained $20 \% \mathrm{GW}$. The present results of lambs' performance are similar to those obtained by El-Deek et al. (2009a) and Zaminur et al. (2013) who used guava by-product in broilers finisher diets and reported that body weight gain, feed intake and FCR in different dietary treatment were almost similar to control group and the differences were not significant. The authors indicated that using GW for feeding broiler chickens at level not more $8 \%$ has no adverse effect on performance. Ibrahim et al. (2016) found that feeding guava leaves mixed with corn offal improved body weight of West African Dwarf 
goats. Díazet al. (2013) fed silage made from leaves and pulp residues of guava with whey to beef cattle. It was found that the best growth performance was obtained from feeding silage of guava residues ensiled with whey in comparison with other agro industrial by-products. In a similar feeding trial (Kamel et al., 2016), rabbits fed diet containing $20 \% \mathrm{GW}$ had growth performance better than the control group.

In laying hens Marquina et al. (2008) and El Deek et al. (2009b) found that feeding guava by-product (GBP) has improved the performance of egg production. Also, Madhava et al. (2004) found that using sun dried guava pomace up to $30 \%$ in diets of pigs had not adversely affected the growth performance. Better performance of using GW in the diet is thought to be healthy because of that GW is rich in antioxidant vitamin C (Bikrisima et al., 2014), antioxidant dietary fiber (AODF) with methoxylated pectin (Uddin et al., 2002) and a blend of amino acids, mainly leucine, glutamic acid, arginine, aspartic acid and glycine (Habib, 1986), fatty acids which increase its nutritive value for feeding (Opute, 1978 and Aly, 1981).

The apparent DC\% of DM and nutrients of experimental diets are presented in Table (3). Results showed insignificant $(P>0.05)$ difference in DC\% of DM, CP, EE, and NFE between different experimental groups. It was observed that $\mathrm{CF}$ digestibility decreased significantly $(P<0.05)$ for lambs fed $20 \% \mathrm{GW}$ in comparison with the control group, while it was insignificantly $(P>0.05)$ decreased when compared with those fed $10 \%$ $\mathrm{GW}$. Crude fiber is the portion of diet that is poorly digested in the gut with prolonged retention time inside the rumen (Mertens, 1997). In a digestibility trial in dairy cattle performed by Paengkoum et al. (2012), it was found that the rumen degradability of DM and CP of guava leaves was better than that of jack fruit leaves when fed to dairy cattle. They indicated that using guava leaves can be used as alternative feed resource for ruminants. Sahin et al. (2002) attributed this positive effect to the antioxidant vitamin C content in GW. Seven, (2008) proposed that vitamin C could hinder the oxidative denaturation of protein, especially under stress.

Table (3): Apparent digestion coefficient (ADC) of diet DM and nutrients in Ossimi male lambs fed on experimental diets.

\begin{tabular}{lcccc}
\hline \multirow{2}{*}{ Item } & \multicolumn{4}{c}{ Treatments } \\
\cline { 2 - 5 } & Control & D1 & D2 & SEM $^{*}$ \\
\hline Digestibility \%: & & & & \\
DM & 60.50 & 60.50 & 60.67 & 0.41 \\
CP & 62.83 & 62.66 & 60.50 & 0.65 \\
CF & $57.66^{\mathrm{a}}$ & $55.33^{\mathrm{ab}}$ & $53.33^{\mathrm{b}}$ & 0.88 \\
EE & 76.20 & 76.30 & 75.53 & 0.40 \\
NFE & 65.63 & 65.40 & 65.36 & 0.32 \\
\hline
\end{tabular}

SEM - Standard error of mean

${ }^{a b}$ within rows means bearing different superscripts differ significantly at $P<0.05$.

Braga et al. (2016) found that the degradability of guava residues was lowered in sheep gut. This lowered digestibility was attributed to the high amount of seed in the waste with combined large amount of acid detergent fiber (ADF) and lignin. Lignin is indigestible substance that may cover the feed particles in the rumen and prevent the attack of microbial digestive enzymes to the diet resulting in decreased digestibility coefficient (Oliveira et al., 2013).

In other trial in rabbit (kamel et al., 2016), DC\% of NDF and ADF were improved for animals fed 20\% $\mathrm{GW}$ in the diet than that of the control. The results of digestibility in this study were also different from those of Kibria et al. (1993) who used guava leaves to evaluate the digestibility coefficient in Black Bengal goats. The authors found that digestibility coefficients were $32.67,48.62,57.64$ and $33.45 \%$ for CP, CF, NFE and EE, respectively. Sharma (1979) indicated that the digestion in goats depended on the nature of the diet, level of feed intake, salivary secretion, manner of rumen fermentation and gut motion. Many factors governing the digestibility of $\mathrm{GW}$, these include the plant varieties, composition and processing methods.

Table (4) shows the results of some biochemical and hematological parameters in the experimental groups. Blood picture and serum biochemistry are important in evaluating the use of non-conventional feed ingredients and their effects on status of animals (Ibrahim et al., 2016). Blood glucose level was found to insignificantly $(P>0.05)$ raised with increasing GW level in the diet. Presence of soluble carbohydrates and digestible nutrients in the diet could increase blood glucose level (Abdollahzadeh et al. 2010). Serum levels of 


\section{Hassan et al.}

proteins and albumin are valuable in reflecting the health of hepatic cells. Serum protein, albumin and globulin values (Table 4 ) of the control and lambs fed GW did not differ significantly $(\mathrm{P}>0.05)$. The values in this study were in the normal range indicating no antinutritional factors that might reduce nutrient absorption in the small intestine, proposing intact hepatocellular functions.

Table (4). Some biochemical and hematological indices of lambs fed the experimental diets

\begin{tabular}{lccccc}
\hline Item & Unit & Control & D1 & D2 & SEM $^{*}$ \\
\hline Biochemical parameters & & & & & \\
Glucose & $(\mathrm{mg} / \mathrm{dl})$ & 117.89 & 135.20 & 156.56 & 9.94 \\
Total protein & $(\mathrm{g} / \mathrm{dl})$ & 4.61 & 5.37 & 6.07 & 0.42 \\
Albumin & $(\mathrm{g} / \mathrm{dl})$ & 3.29 & 3.56 & 3.41 & 0.15 \\
Globulin & $(\mathrm{g} / \mathrm{dl})$ & 1.32 & 1.80 & 2.65 & 0.34 \\
Total cholesterol & $(\mathrm{mg} / \mathrm{dl})$ & 85.39 & 79.03 & 74.95 & 2.59 \\
Urea & $(\mathrm{mg} / \mathrm{dl})$ & 42.03 & 46.45 & 49.44 & 2.73 \\
Creatinine & $(\mathrm{mg} / \mathrm{dl})$ & 0.72 & 0.83 & 0.92 & 0.05 \\
Hematological parameters & & & & & \\
Red blood cells $(\mathrm{RBCs})$ & $\left(10^{6} / \mu 1\right)$ & 10.96 & 11.23 & 10.98 & 0.21 \\
Hemoglobin(Hb) & $(\mathrm{gm} / \mathrm{dl})$ & 12.66 & 13.26 & 13.00 & 0.23 \\
PCV & $\%$ & 49.53 & 51.36 & 51.10 & 1.06 \\
MCV & $\mathrm{fl}$ & 45.18 & 45.71 & 46.54 & 0.45 \\
MCH & $\mathrm{pg}$ & 11.54 & 11.82 & 11.84 & 0.10 \\
MCHC & $\%$ & 25.55 & 25.86 & 25.48 & 0.22 \\
White blood cells (WBCs) & $\left(10^{3} / \mu \mathrm{l}\right)$ & 14.33 & 13.67 & 12.00 & 0.73 \\
Lymphocyte & $\%$ & 73.46 & 71.23 & 73.66 & 1.75 \\
Monocyte & $\%$ & 5.26 & 4.40 & 5.46 & 0.56 \\
Granulocyte & $\%$ & 21.26 & 24.36 & 20.86 & 1.49 \\
\hline *SEM - Standard error of mean. & & & & & \\
PCV: Packed cell volume. & & & & & \\
MCV: Mean corpuscular volume. & & & & & \\
MCH: Mean corpuscular hemoglobin. & & & & & \\
MCHC: Mean corpuscular hemoglobin concentration & & & &
\end{tabular}

Constant serum globulin level can assess animal adaptation to stress and indicates that the lambs were not affected by a disease that would cause an excessive production of antibodies through gamma globulin production (Kaneko et al., 2008). Increasing total proteins and globulin levels with inclusion of GW in the diet might due to its high content of neutral detergent insoluble nitrogen (NDIN), offering available nitrogen for rumen microorganisms and consequently increased protein absorption in the intestine (Braga et al., 2016). Results of this study can be compared favorably with those of (Ibrahim et al., 2016), who found that total protein, albumin and creatinine values of the control and goats fed guava leaf meal were significantly similar. The authors concluded that feeding guava leaf meal up to $10 \%$ of the ration had no harmful effect on blood and serum biochemical indices of the goat. Concerning results of total serum cholesterol in the experimental groups fed GW (Table 4), there was an insignificant reduction $(P>0.05)$ in the concentration. It was indicated that the high vitamin $\mathrm{C}$ content in $\mathrm{GW}$ is responsible for scavenging effect of free radical in the blood, resulting in reducing total cholesterol level (Singh and Rastogi, 1997). The serum urea and creatinine levels were insignificantly $(P>0.05)$ increased with animals fed GW. This higher concentration may be attributed to increased absorption of ruminal ammonia (Abas et al., 2007).

Red blood cells and platelets counts, PCV, $\mathrm{Hb}, \mathrm{MCV}, \mathrm{MCH}$, and MCHC (Table 4), are indices used for evaluation of bone marrow capacity of blood cells production and diagnosis of anemia (Peters et al., 2012; Etim et al., 2014; Awodie et al., 2005 and Chineke et al., 2006). Hematological results in this study revealed no significant change $(P>0.05)$ between experimental groups. For RBCs count and MCHC, it was no difference between control group and those fed diet with GW and the values were within the normal range. Concerning $\mathrm{Hb}, \mathrm{PCV}, \mathrm{MCV}$, and MCHC, there was a slight but insignificant $(P>0.05)$ increase in their values when compared with the control. These results were positively comparable to that of Ibrahim et al. (2016), who fed guava leaf meal (10\% of the ration) to African Dwarf Goats. These blood results indicate a normal 
healthy condition of the animals (Chineke et al., 2006 and Etim et al., 2010). The normal values of $\mathrm{Hb}$ indicated that the diet fed to lambs contained high protein quality (Bello and Tsado, 2014), while the normal PCV values proposed absence of toxic substances such as hemaglutinin which has a bad impact on blood formation (Bello and Tsado, 2013; and Oyawoya and Ogunkunle 1998). As reported previously (Radostits et al., 1994; Adamu et al., 2008 and Etim et al., 2014), hematological values of sheep are significantly affected by nutritional condition. Thus blood results in this study indicate that feeding diet containing GW to lambs were balanced and had no adverse effect on blood and health status. Values of WBC, lymphocytes, monocytes, and granulocytes in this study of lambs fed GW were favorably comparable to control group and within the normal range of Ossimi breed. According to Bello and Tsado (2014), these results pointed out that feeding ration containing GW did not affect the immune system.

Results of carcass characteristics and analysis of rib-eye area (lean and fat) of the experimental lambs are presented in Table (5). Values of carcass traits (hot carcass, dressing percentage, prime and second cuts, and weights of some internal organs) of growing lambs fed GW were statistically similar to the control group.

Table (5): Carcass characteristics and analysis of rib-eye area (lean and fat) of the Ossimi growing lambs fed the experimental diets.

\begin{tabular}{|c|c|c|c|c|c|}
\hline Item & Unit & Control & D1 & D2 & $S E M^{*}$ \\
\hline Hot carcass weight & $\mathrm{kg}$ & 33.13 & 29.83 & 30.33 & 1.23 \\
\hline Dressing percent & $\%$ & 56.73 & 55.63 & 54.46 & 0.81 \\
\hline Prime cuts weight & $\mathrm{kg}$ & 23.93 & 20.93 & 20.63 & 0.98 \\
\hline Second cuts weight & $\mathrm{kg}$ & 9.15 & 8.87 & 9.63 & 0.47 \\
\hline Heart & $\mathrm{kg}$ & 0.16 & 0.17 & 0.16 & 0.003 \\
\hline Kidneys & $\mathrm{kg}$ & 0.38 & 0.35 & 0.28 & 0.018 \\
\hline Liver & $\mathrm{kg}$ & 0.86 & 0.83 & 0.73 & 0.043 \\
\hline Spleen & $\mathrm{kg}$ & 0.073 & 0.056 & 0.057 & 0.0036 \\
\hline Tests & $\mathrm{kg}$ & 0.42 & 0.45 & 0.48 & 0.026 \\
\hline \multicolumn{6}{|c|}{ Chemical composition of rib-eye area (lean and fat) } \\
\hline Moisture & $\%$ & 69.33 & 69.66 & 69.50 & 0.20 \\
\hline $\mathrm{CP}$ & $\%$ & 15.97 & 16.18 & 15.94 & 0.11 \\
\hline EE & $\%$ & 27.28 & 27.18 & 26.98 & 0.10 \\
\hline Ash & $\%$ & 3.03 & 3.07 & 3.05 & 0.05 \\
\hline
\end{tabular}

These results are favorably compared with those of Silva et al. (2014), who found that feeding guava byproduct (GBP) to growing sheep at level up to $16.4 \%$ of the diet produced carcasses convenient to the consumers, while feeding GBP at level $24.6 \%$ of the diet produced carcasses of inferior traits compared to the control. Even in case of feeding sun dried guava pomace up to $30 \%$ in the diet of pigs (Madhava et al., 2004), carcass traits were not adversely affected. Similarly, feeding GW to New Zealand rabbits at $20 \%$ of the diet resulted in carcass quality parameters not different from the control (Kamel et al., 2016). In other study of feeding the European quail guava residue as a partial substitution of corn in the diet (up to 10\%), there were no significant difference between treated and control groups in terms of carcass yield, breast, drumstick, thigh, wings, back, neck, head, feet, heart, liver and gizzard (Camelo et al., 2015).It was concluded that feeding Cobb broiler chicks GW up to 12\% (Lira et al., 2011) or up to 8\% (El Deek et al., 2009a) of the diet revealed no significant difference between groups in carcass traits. Chemical analysis of lamb's meat shows non-significant differences between experimental groups regarding moisture, $\mathrm{CP}, \mathrm{EE}$ and ash percentages as presented in Table (5). In the study of El-Sayed et al. (2013), broiler chicks were fed dried guava leaves as $1 \%$ of the diet. The results of meat composition of breast muscle showed increase in DM and decrease in ash and EE contents, while no change in CP level. In another study Abdelhamid and Soliman (2012), the chemical composition of meat from Nile Tilapia fed guava leaves at a level of $1 \%$ of the diet revealed significantly higher CP and EE contents and no significant difference in DM and ash percentages.

Economically, TFC (Table 6) included the cost of equipment $(8.30 \mathrm{LE})$, building depreciation (16.60LE), water and electricity (3.30 LE), labor $(33.0 \mathrm{LE})$, and veterinary management $(2.70 \mathrm{LE})$. Therefore, 


\section{Hassan et al.}

the TFC was 63.9 LE/animal in each group. Concerning the TVC, there were non-significant differences $(P>0.05)$ among the experimental groups.

Table (6). Effect of feeding GW to growing lambs on the economic efficiency parameters.

\begin{tabular}{|c|c|c|c|c|}
\hline Item (LE/animal) & Control & D1 & D2 & SEM $^{*}$ \\
\hline Equipment depreciation & 8.30 & 8.30 & 8.30 & \\
\hline Building depreciation & 16.60 & 16.60 & 16.60 & \\
\hline Water and electricity & 3.30 & 3.30 & 3.30 & \\
\hline Labor & 33 & 33 & 33 & \\
\hline Veterinary management & 2.70 & 2.70 & 2.70 & \\
\hline TFC & 63.9 & 63.9 & 63.9 & \\
\hline Ration cost (L.E/ton) & 2088.56 & 2037.37 & 1961.43 & \\
\hline Feed cost & $518.52^{\mathrm{b}}$ & $512.23^{\mathrm{ab}}$ & $491.99^{\mathrm{a}}$ & 9.12 \\
\hline Purchased sheep & 1136.7 & 1143.3 & 1133.3 & 67.9 \\
\hline TVC & 1655.19 & 1655.56 & 1625.33 & 76.53 \\
\hline TC & 1719.09 & 1719.46 & 1689.23 & 76.54 \\
\hline Sheep sales & 1926.7 & 1926.7 & 1953.3 & 84.7 \\
\hline Wool sales & 25 & 25 & 25 & \\
\hline Litter sales & 20 & 20 & 20 & \\
\hline TR & 1971.7 & 1971.7 & 1998.3 & 84.7 \\
\hline NP & 252.58 & 252.20 & 309.11 & 27.2 \\
\hline \multicolumn{5}{|c|}{ LE: Egyptian Pound, TFC: Total fixed costs. } \\
\hline \multicolumn{5}{|c|}{ TC: Total costs, TVC: Total variable costs. } \\
\hline \multicolumn{5}{|c|}{ TR: Total returns, NP: Net profit. } \\
\hline "SEM - Standard error & & & & \\
\hline
\end{tabular}

The differences in the TVC values were due to the feed cost (cost of total feed intake); it was (LE 518.52) for control group and were (LE 512.23 and 491.99/animal for GW 10\% and 20\%, respectively). Consequently, the TC values were (LE1719.09; 1719.46 and LE 1689.23/animal) for the control, D1 and D2, respectively. So, the results of TVC and TC indicate that including GW with the percentage of $20 \%$ in sheep diet reduced the production cost. Comparatively with the control diet, the results showed that the cost of one ton of feed was reduced for both diet D1 and diet D2.The feed cost/ ton of feed saved about LE 51.19 and LE 127.13/ ton for D1 and D2, respectively; meanwhile, the control diet have the highest cost/ton. Also, the diet D2 containing 20\% GW saved LE 75.94 when compared to diet D1 (10\% GW).

The obtained TR values (Table 6) including wool and litter sales revealed that were not significantly different $(P>0.05)$ among the three experimental groups. Net profit was insignificantly higher $(P>0.05)$ for D2 experimental group (LE 309.11/animal), than that for both the control group and D1 (LE 252.58 /animal and LE 252.20, respectively). Low NP value for D1 was due to relatively higher price of purchasing lambs and higher feed intake which might be due to environmental or genetic individual variations between animals. In this study, it was concluded that diet containing $20 \% \mathrm{GW}$ can reduce feed costs by about $6 \%$ and raise the profits of the total production income by about $22 \%$.

\section{CONCLUSION}

Results of this study showed that dried GW can be used satisfactory in sheep diet at level of $20 \%$ without any adverse effects the lamb's growth, feed conversion, digestibility, carcass traits and some blood parameters. In case of economic efficiency, addition of GW to the diet reduced the feed costs, which represent a valuable factor in animal production. More studies are required to investigate the effect of including more quantities of GW in the diets of growing sheep and the possibility to add natural feed additives to improve digestibility and feed conversion. 


\section{Acknowledgment}

The authors are grateful to the staff of the Animal Farm, Faculty of Agriculture, Benha University (www.bu.edu.eg) for their technical assistant. Special thanks were to assistant professor doctor Ayman Samir Farid, who received financial support from Scientific Research Fund, Benha University, Egypt.

\section{REFERENCES}

Abas I.; H.C. Kutay; R. Kahraman; N.Y. Toker; D. Özçelik; F. Ates and A. Kaçakci (2007).Effects of organic acid and bacterial direct-feed microbial on fattening performance of Kivircik-Male yearling lambs. Pakistan Journal of Nutrition 6 (2): 149-154.

Abdelhamid, A.M. and A.A. Soliman (2012). Possibility of using dried Leaves of guava and camphor trees in Tilapia diets. Journal of the Arabian Aquaculture Society 7, 91-108.

Abdollahzadeh, F.; R. Pirmohammadi; P. Farhoomand; M. Romero-Huelva; E. Ramos-Morales; E.F. Fatehi and F.F. Pazhoh (2010). The effect of ensiled Molina-Alcaide, 2012. Nutrient utilization, ruminal mixed tomato and apple pomace on Holstein dairy fermentation, microbial abundances and milk yield cow. Ital. J Anim. Sci., 9: 212-216.

Adamu, S.; A. Thomas; N.M. Iseh; M.Y. Fatihumi and K.A.N. Esieno (2008). Normal values of haematology of Nigeria adopted albino rats (Rattusnorvegicus) in Zaria. Proc. $31^{\text {st }}$. Ann. Conf. Nig. Soc. Anim. Production.

Adeyinka, I.A. and I.D. Mohammed (2006).Relationship of live weight and linear body measurement in two breeds of goat of Northern Nigeria. J Anim Vet Adv, 5: 891-893.

AL-Shanti, H.A.; A.M. Kholif; K.J.AL-Shakhrit; M.F. AL-Banna and I.E.A. Showayb (2013). Use of crushed date seeds in feeding growing Assaf lambs. Egyptian Journal of Sheep and Goat Sciences 8, 65-73.

Aly, A.M. (1981). Studies on the unsoponifiable matter of some vegetable oils. M.Sc. Thesis, Faculty of Agriculture, Minufiya University, Egypt.

AOAC (1995). Official Methods of Analysis of the Association of Official Analytical Chemists, $16^{\text {th }}$ edition.

Asmare, B.; S. Melaku and K.J. Peters (2010). Supplementation of Farta sheep fed hay with graded levels of concentrate mix consisting of noug seed meal and rice bran. Trop Anim Health Prod 42, 1345-1352.

Awodie, S.; J.O. Ayo; A.D. Atodo and T. Dzende (2005). Some hematological parameters and the erythrocyte osmotic fragility in the laughing dove (Streptopellasenegalensis) and the village weaner bird (Ploceuscucullatus). Proc. 10th Annual conf. Anim. Sci. Assoc., Nigeria; 384-387.

Belifield and Goldberg (1971). Ann. Biol. Clin. 44: 686.

Bellaver C.; E.A.P. Figueiredo; E.R. oliveira and E.K.P. Pant (1983).Carcass characteristics of goats and sheep in Northeast Brazil. pesq. A andopec. bras, brasília, 18 (3): 301-309.

Bello, A.A. and D.N. Tsado (2013). Feed intake and nutrient digestibility of growing Yankasa rams fed sorghum stover supplemented with graded levels of dried poultry droppings based diet. Asian Journal of Animal Science. 7(2): 56-63.

Bello, A.A. and D.N. Tsado (2014). Quality and sensory evaluation of meat from Yankasa rams fed sorghum stover supplemented with varying levels of dried poultry droppings based diet. Int. J. of Agric. And Food Sci. Tech. 5 (2): 1- 8.

Bikrisima, S. H. L.; L. D. Mahfudz and N. Suthama (2014). Production capacity of broiler chickens fed red guava fruit meal as source of natural antioxidant. http://repository.unhas.ac.id/handle/123456789/12617.

Braga, A.P.; A.V.A.F. Amâncio; J.S.Gonçalves; L.S.L.C.Assis; C.M.S. Souza; I.S.A.S. Maia and D.G.F. Gerra (2016). Ruminal degradability of agro-industrial fruit residues. Semina: Ciências Agrárias, Londrina, v. 37, n. 1, p. 279-292, Jan. /fev. 


\section{Hassan et al.}

Camelo, L.C.L.; G.R.Q. Lana; M.J.B.D. Santos; Y.A.R.P. Camelo; A.L. Marinho and C.B. Rabello (2015).Inclusion of guava wastes in the diet of European quails. Ciência Animal Brasileira, 16 (3)343349.

Chineke, C.A.; A.G. Ologun and C.O.N. Ikeobi (2006).Hematological parameters in rabbit breeds and crosses in humid tropics. Pakistan Journal of Biological science. 9: 2102-2106.

Díaz, B.; A. Elías and E.C. Valiño (2013).Nutritional and economical efficiency of three biosilages from agro industrial wastes in beef cattle. Cuban Journal of Agricultural Science, 47(2):143-150.

Duncan, D.B. (1955). Multiple range and multiple F tests. Biometrics 11, 1-42.

El-Deek, A.A.; M.A. Asar; S.M. Hamdy and A.A. Abdalla (2009a).Utilization of guava by- products in broiler finisher diets. Egypt. Poult. Sci. 29, 53-75.

El-Deek A.A.; S.M. Hamdy; Y.A. Attia and A.M. El-Shahat (2009b). Guava by-product meal processed in various ways and fed in differing amounts as a component in laying hen diets. International Journal of Poultry Science 8 (9): 866-874.

El-Sayed, M.R.; D. Ibrahim and B.M. El-Sayed (2013).Effect of supplementation of broiler diets with guava leaves and/or olive oil on growth, meat composition, blood metabolites and immune response. Benha Veterinary Medical Journal, 25(2):23-32.

EL-Tahaway, A.S. (2007).Cattle diseases and their effects on economic and productive efficiency of dairy farms. Ph.D. Faculty of Veterinary Medicine, Alexandria University.

Etim, N.N. (2010). Physiological and reproductive responses of rabbit does to Aspiliaafricana. M. SC. Thesis, Michael Okpara University of Agriculture, Umudike, Abia State.

Etim, N.N.; G.E. Enyenihi; U. Akpabio and E.A. Offiong (2014).Effects of nutrition on haematology of rabbits: A review. European Scientific Journal.10 (30): 413-424.

Habib, M.A. (1986). Studies on the lipid and protein composition of guava seed (psidiuymguayava).Food Chem. 22: 7-16.

Hankins, O.G. and P.E. Howe (1946).Estimation of the composition of beef carcass cuts. USDA: Washington (Technical Bulletin, 926).

Husdan and Rapaport (1968).Estimation of creatinine by the Jaffe reaction. Clinic chemist 14:222-226.

Ibrahim, O.A.; A.A. Hyacinth; A. Terzungwe and O.L. Danie (2016). Growth performance, hematological and serum biochemical profiles of West African Dwarf goats fed dietary guava leaf meal. International Journal of Agriculture and Biosciences. 5(4): 188-191.

Kamel E.R.; F. Abdel-Fattah; H.S. El-Qaliouby and E.A.A. Mahmoud (2016). Response of New Zealand rabbits to diet containing guava waste (PsidiumGuaijava L.): 1. Effect on growth performance, diet digestibility and economic efficiency. Alexandria Journal of Veterinary Sciences, July. 50 (1): 24-35.

Kaneko, J.J.; J.W. Harvey and M. Bruss (2008). Clinical biochemistry of domestic animals. Amsterdam ; Boston, Academic Press/Elsevier.

Kibria, S.S.; T.N. Nahar and M.M. MIA (1993). Evaluation of important tree leaves available in Bangladesh using Black Bengal goats Indian Journal of Animal Sciences 63, 989-992.

Lira, R.C.; C.B.V. Rabello; E.P. da Silva; P.V. Ferreira; M.C.M. Ludke and M.E.V. Costa (2011). Chemical composition and energy value of guava and tomato wastes for broilers chickens at different ages. Revista Brasileira de Zootecnia, v.40, n.5, p.1019-1024.

Lira, R.C.; C.B.V. Rabello; P.V.Ferreira; G.R.Q. Lana; J.V. Lüdke; J. Dutra and M. Wilson (2009). Inclusion of guava wastes in feed for broiler chickens. Revista Brasileira de Zootecnia 38, 2401-2407.

Liza, S.M. (2012). Effect of Days open, dry period and calving interval on economic and productive efficiency of dairy farms,. M. V. Sc , Faculty of Veterinary Medicine Banha University - Egypt.

Macias-Cruz, U.; J.A. Quintero-Elisea; L. Avendano-Reyes; A. Correa-Calderon; F.D. Alvarez-Valenzuela; S.A. Soto-Navarro; F.A. Lucero-Magana and A. Gonzalez-Reyna (2010). Buffel grass (Cenchrus ciliaria 
L.) substitution for orange pulp on intake, digestibility, and performance of hairsheep lambs. Trop Anim Health Prod 42, 223-232.

Madhava, R.T.; A. Ravi; R.D. Srinivasa; P.J. Rama; R.P. Sudhakara and R. Z. Prabhakara (2004). Effect of inclusion of guava (Psidiumguajava) Pomace in pig diets on growth performance, nutrient utilization and carcass characteristics. Animal Nutrition and Technology, vol. 4: (1), 43-52.

Marquina, V., L.; J. Araujo; A. Ruíz; M. Rodríguez and P. Vit (2008). Composition and antioxidant capacity of the guava (Psidiumguajava L.) fruit pulp and jam]. Archive Latinoam Nutr., 58: 98-102.

McDonald, P.; R.A. Edward; J.F.D. Greenhalgh and G.A. Morgan (2002). Animal Nutrition 6th ed. Pearson Educational Limited. Edinburgh, Great Britain. Pp 544.

Melo, P.B.; K.B. Bergamaschi; A.P. Tiveron; A.P. Massarioli; T.L.C. Oldoni; M.C. Zanus; G,E. Pereira and S.M. Alencar (2011). Composiçãofenólica e atividadeantioxidante de resíduosagroindustriais. Ciência Rural,41(6), 1088-1093. http://dx.doi.org/10.1590/S0103-84782011000600027.

Mertens, D.R. (1997). Creating a system for meeting the fiber requirements of dairy cows. Journal of Dairy Science, Madison, v. 80, n. 7, p. 1463-1481.

NRC (1985). Nutrient requirements of sheep, sixes revised edition. Subcommittee on sheep nutrition, committee of animal nutrition, board on agriculture, National Research Council.

Oliveira, E.R.; F.P. Monção; R.H.T.B. Góes; A.M.A. Gabriel; L.V. Moura; B. Lempp; D.E. Graciano and A.T.C. Tachetto (2013). Degradaçãoruminal da fibraemdetergenteneutro de gramínea do gêneroCynodon spp. emquatroidades de corte. Revista Agrarian, Dourados, v. 6, n. 20, p. 205-214.

Omar, M.A.E. (2009). Economic study on the productive and reproductive efficiency in dairy farms in relation to veterinary management. . Ph.D. of Vet. Medical Science, Zagazig University, Egypt.

Omena, C.M.B.; I.B. Valentim; G.V.S. Guedes; L.A. Rabelo; C.M. Mano; E.J.H. Bechara; A.C.H.F. Sawaya; M.T.S. Trevisan; J.G. Costa; R.C.S. Ferreira; A.E.G. Sant' Ana and M.O.F. Goulart (2012). Antioxidant, anti-acetylcholinesterase and cytotoxic activities of ethanol extracts of peel, pulp and seeds of exotic Brazilian fruits. Antioxidant, anti-acetylcholinesterase and cytotoxic activities in fruits. Food Research International, 49 (1), 334-344. http://dx.doi.org/10.1016/j.foodres.2012.07.010.

Opute, E.I. (1978). The component fatty acids of psidiuymguayava seedless. J. Sci. Food Agric., 29: 737.

Oyawoya, B.M. and H.N. Ogunkunle (1998). Biochemical and hematological reference values in normal experimental animal. Masson, New York, 2004; 212-218.

Paengkoum, P.; S.T raiyakun; J. Khotsakdee; S. Srisaikham and S. Paengkoum (2012). Evaluating the degradability of the Guava and Jack fruit leaves using in Sacco technique and three-step techniques. Pakistan Journal of Nutrition, 11 (1): 16-20.

Peters, S.O.; H.H. Gunn and I.G. Imumorin (2012).Hematological studies on frezzled and naked neck genotypes of Nigerian chickens. Tropical Animal Health Production. 43(8): 631-8.

Radostits, O.M.; C.C. Gays and D.C. Blood (1994).Veterinary Medicine: A textbook of disease of cattle, sheep, goats, pigs and horses. W. B. Saunders; 304.

Sahin, K.; N. Sahin and O. Kucuk (2002). Effects of dietary chromium and ascorbic acid supplementation on digestion of nutrients, serum antioxidant status, and mineral concentrations in laying hens reared at a low ambient temperature. Biological Trace Element Research, Volume 87, Issue 1: 113-124.

Sankhyan, L.P. (1983). Introduction to farm management. . Tata MC-Grow Hill Publishing Company Limited New Delhi.

Santos, E.L., M.C.M.M. Ludke and J.M. Barbosa (2009). Digestibilidadeaparente do farelo de coco e do resíduo de goiabaparatilápia do Nilo. Caatinga, v.22, n.2:175-180.

Seven, P.T. (2008).The Effects of dietary Turkish propolis and vitamin C on performance, digestibility, egg production and egg quality in laying hens under different environmental temperatures. Asian-Aust. J. Anim. Sci. Vol. 21, No. 8: 1164 - 1170. 


\section{Hassan et al.}

Sharma, K. (1979). Efficiency of feed utilization in goats. In: Proc. of Summer Institute on Goat Production. Central Institute for Research on Goat, ICAR. UP, India, pp. 223-240.

Shi, F.H.; L. Fang; Q.X. Meng; H. Wu; J.P. Du; X.X. Xie; L.P. Ren; Z.M. Zhou and B. Zhou (2014). Effects of partial or total replacement of maize with alternative feed source on digestibility, growth performance, blood metabolites and economics in limousin crossbred cattle. Asian-Australian J. Anim Sci., 27, 14431451.

Silva, N.V.; R.G. Costa; G.R. Medeiros; A.N. Medeiros; S. Gonzaga Neto; M.F. Cezar and M.C.A. Cavalcanti (2014). Carcass characteristics of sheep fed with guava by-product. Arch. Zootec. 63 (241): 25-35.

Singh, R.B. and S.S. Rastogi (1997). Effects of plasma ascorbic acid and coronary risk factors of adding guava fruit to the usual diet in hypertensive with mild to moderate hypercholesterolemia. $\mathrm{J}$ of Nutrand Env Med. 7 (1): 5-10

Uddin, M.S.; M.N.A. Hawlader; L. Ding and A.S. Mujumdar (2002).Degradation of ascorbic acid in dried guava during storage. J. Food Eng., 51: 21-26.

Van Soest, P.J.; J.B. Robertson and B.A. Lewis (1991). Methods for dietary fiber, neutral detergent fiber and non-starch polysaccharides in relation to animal nutrition. J. Dairy Sci., vol. 74, p. 3583-3597.

Zaminur, R.; M.N. Siddiqui; M.A. Khatun and M. Kamruzzaman (2013). Effect of guava (Psidium guajava) leaf meal on production performances and antimicrobial sensitivity in commercial broiler. Journal of Natural Products 6, 177-187.

تأثثير التخذيـة بمخلف الجوافـة على أداء النمـو وهضم الغذاء وخصـائص الذبيحة والكفـاءة الاقتصـادية فى حمـلان الأوسيمى

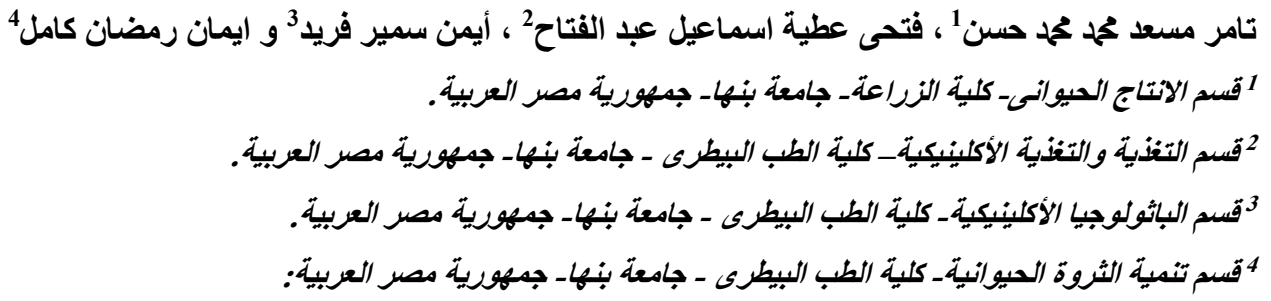

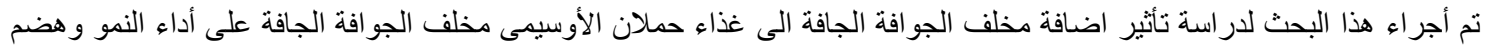

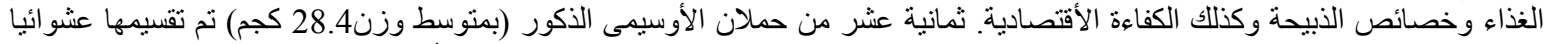

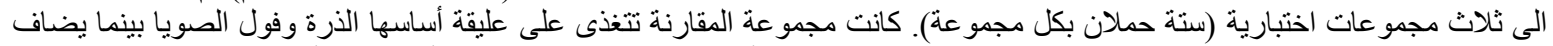

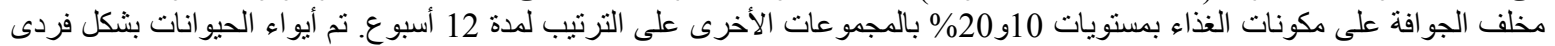

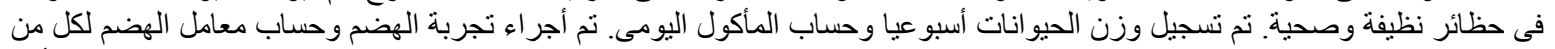

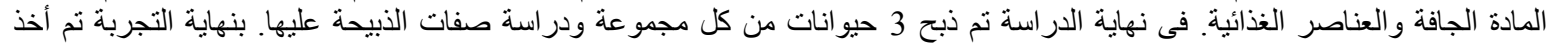

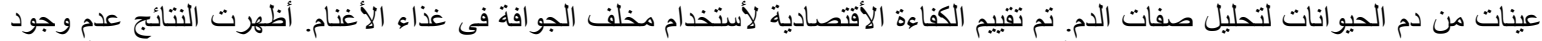

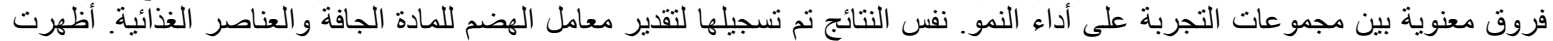

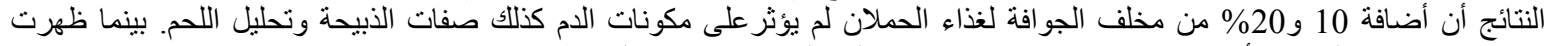

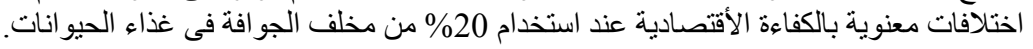

نخلص من ذلك الى أن مخلف الجو افة يمكن أستخدامه بشكل فعال عند مستوى 20\% من النظام الغذائى دون نأثيثر سلبى على أداء النمو و الهضم و صفات الذبيحة أو العلامات الصحية لحملان الأوسيمى. 